\title{
METODE JIGSAW DALAM PEMBELAJARAN MATEMATIKA UNTUK MENINGKATKAN HASIL BELAJAR PESERTA DIDIK KELAS V DI MI DARUT TAQWA
}

\author{
Makherus Sholeh \\ IAIN Antasari Banjarmasin \\ makheruss@gmail.com
}

\begin{abstract}
With student-centered jigsaw discussion lively and quality learning. Result of research: 1) Learning through method of discussion of jigsaw technique in the subject of Mathematics on the subject of integer counting operation is a training-based teaching that uses exercise questions as a context for students to learn about critical thinking and problem solving skills together and in the form of reinforcement, and to acquire essential knowledge and concepts from the subject matter, 2) Jigsaw technique discussion method is very effective to improve students' learning success. This is evidenced by the level of student learning success is quite satisfactory which can be known from success indicators in the form of student learning outcomes and learning process. The learning process is crucial to the learning outcomes.
\end{abstract}

Key Word: Jigsaw, learning process, learning outcomes

\begin{abstract}
ABSTRAK
Dengan diskusi jigsaw yang berpusat pada siswa pembelajaran terasa hidup dan berkualitas. Hasil penelitian: 1) Pembelajaran melalui metode diskusi teknik jigsaw pada pelajaran Matematika pada pokok bahasan operasi hitung bilangan bulat merupakan pengajaran berbasis latihan yang menggunakan soal-soal latihan sebagai suatu konteks bagi siswa untuk belajar tentang cara berpikir kritis dan keterampilan memecahkan masalah secara bersama-sama dan berbentuk penguatan, serta untuk memperoleh pengetahuan dan konsep yang esensial dari materi pelajaran, 2) Metode diskusi teknik jigsaw sangat efektif untuk meningkatkan keberhasilan berlajar siswa. Hal ini dibuktikan dengan tingkat keberhasilan belajar siswa yang cukup memuaskan yang dapat diketahui dari indikator keberhasilan yang berupa nilai hasil belajar siswa dan proses pembelajaran. Proses belajar sangat menentukan hasil belajar.
\end{abstract}

Kata Kunci: Jigsaw, proses belajar, hasil belajar

\section{PENDAHULUAN}

Pada dasarnya menurut ajaran Islam manusia adalah makhluk yang paling sempurna dan berbeda dengan makhluk lain karena manusia memiliki akal. Untuk itu Islam memerintahkan kepada umat manusia untuk mencari ilmu pengetahuan, sehingga manusia itu sendiri tidak lepas dengan pendidikan dalam kehidupannya untuk memperoleh pengembangan bagi pendidikannya sesuai dengan bakat dan potensi yang dimilikinya. Dengan demikian, pelaksanaan pendidikan sebaiknya menggunakan teori yang terbukti dan teruji kebenarannya seperti halnya $\mathrm{Ki}$ Hajar Dewantara yang berpendapat bahwa, "Pendidikan hendaknya diselenggarakan secara terorganisir antara sekolah, masyarakat dan keluarga yang sangat internal, yang biasanya disebut dengan istilah Tri Pusat Pendidikan. Dalam hal ini tiga elemen pendidikan tersebut sangat diharapkan untuk bertanggung jawab serta membantu peserta didik agar mereka mampu meraih prestasi pendidikan sebagaimana tujuan pendidikan nasional.

Hal itu sesuai dengan salah satu amanat dari UUD 1945 yang mengupayakan untuk mencerdaskan kehidupan bangsa, yang mana dijelaskan dalam Undang-undang nomor 20 tahun 2003 tentang Sistem Pendidikan Nasional bahwa pendidikan nasional bertujuan mencerdaskan kehidupan bangsa dan mengembangkan manusia Indonesia sepenuhnya yaitu manusia yang beriman dan bertakwa terhadap Tuhan Yang Maha 
Esa dan berbudi pekerti yang luhur, memiliki pengetahuian dan ketrampilan, sehat jasmani dan rohani, berkepribadian mantap dan mandiri serta rasa tanggung jawab kemasyarakatan dan kebangsaan. Sehingga di dalam dasar atau tujuan Pendidikan Nasional disebutkan bahwa, tujuan pendidikan adalah untuk meningkatkan kecerdasan bangsa. Namun kenyataanya masalah yang sangat menonjol utamanya dalam pendidikan sekolah adalah hasil belajar peserta didik yang belum memuaskan terutama pelajaran matematika. Hal ini bisa didukung dari perolehan hasil nilai ujian nasional peserta didik yang setiap tahunnya tidak meluluskan beratus-ratus peserta didik karena pelajaran matematika. Selain itu sering kita jumpai peserta didik yang sering mengeluh tentang pelajaran matematika disekolahnya. Mereka mengatakan tidak menyukai matematika karena selalu mendapatkan nilai yang tidak memuaskan.

Kegagalan mengajar tetap merupakan kegagalan, apapun sebabnya, baik dari unsur murid, guru maupun materi ajar. Kalau anak tidak belajar dengan baik, tentu ada kekurangannya dalam hal mengajar. Seorang guru hendaknya tidak hanya menggunakan satu metode saja dalam mengajar. Mengingat penggunaan metode secara bervariasi dapat menghidupkan dan meningkatkan perhatian peserta didik dalam memahami pelajaran. Sehingga dapat dipahami bahwa dengan menggunakan metode yang tepat, bahan pelajaran akan dapat ditangkap, dipahami, dan digunakan oleh peserta didik dengan baik yang pada gilirannya tujuan yang telah dirumuskan dapat tercapai. Hal yang merisaukan dalam dunia pendidikan adalah masih banyaknya guru yang setia menggunakan metode belajar konvensional. Penggunaan metode belajar konvensional (tradisional) yang kurang efektif cenderung akan menimbulkan kejenuhan pada peserta didik dalam mengikuti pelajaran sehingga akan dapat menimbulkan dampak mempengaruhi hasil belajar. Pada sistem pengajaran yang tradisional, penggunaan sumber pembelajaran masih terbatas pada informasi yang disampaikan oleh guru dan ditambah sedikit dari buku (Suwarna 2005: 115). Jadi metode yang selama ini digunakan guru dalam mengajar dirasa kurang efektif, karena hanya mendengarkan apa yang diucapkan guru, kemudian mencatat dan menghafal sehingga aktivitas belajar peserta didik sangat kurang berkembang.

Berpijak dari pernyataan di atas, maka kemampuan guru untuk menggunakan metode yang tepat dalam mengajar akan menentukan keberhasilan proses belajar mengajar itu sendiri. Sedangkan mengingat metode mengajar jumlahnya relatif banyak, tentu saja penggunaannya disesuaikan dengan tujuan apa yang akan dicapai serta sifat dari materi yang akan diberikan. Penggunaan metode yang tepat ini juga bukan ditentukan oleh banyaknya metode atau macamnya metode mengajar yang digunakan. Mengingat penggunaan metode secara bervariasi dapat menghidupkan dan meningkatkan perhatian pada pelajaran serta menunjang tercapainya tujuan pendidikan, maka seorang guru hendaknya tidak selalu menaruh kepercayaan pada pemakaian satu macam metode mengajar saja. Guru yang terlalu simpatik terhadap penggunaan satu jenis metode dapat membawa dampak negatif terhadap pelaksanaan proses belajar mengajar bahkan dapat berakibat gagalnya pencapaian tujuan yang telah ditetapkan atau dirumuskan.

Seorang guru dalam mengajar hanya menggunakan metode drill atau ceramah saja, misalnya maka peserta didik akan cenderung bersikap pasif dan mudah bosan. Akibatnya perhatian mereka terhadap proses belajar mengajar tidak dapat berjalan lancar. Menurut Suryobroto (1997: 43) Metode mengajar yang baik adalah metode mangajar yang dapat menumbuhkan kegiatan belajar mengajar peserta didik, serta menggunakan metode 
mengajar secara bervariasi. Seorang guru harus mampu memilih metode mengajar yang sesuai, dapat memenuhi beberapa persyaratan dan ketentuan demi tercapainya tujuan pendidikan, dan memperhatikan respon balik dari peserta didik. Dengan langkah tersebut dapat diketahui kemampuan peserta didik serta kesesuaian metode dengan materi dan keinginan peserta didik, sehingga prestasi belajar peserta didik bisa meningkat. Semakin tinggi dan luas pendidikan dan penguasaan materi yang yang dimiliki guru, baik cara mengajarnya, maupun penampilannya, tentunya akan makin mempengaruhi terhadap mutu pengajarannya. Keberhasilan dalam melaksanakan suatu pengajaran sebagian besar ditentukan oleh pilihan bahan dan pemakaian metode yang tepat(Trigan 1990 :41). Sehingga dari sini akan semakin jelas bahwa keberhasilan proses pendidikan sebagian besar dipengaruhi oleh cara pengajarannya.

Sedangkan ciri proses belajar mengajar yang berhasil, salah satunya adalah dilihat dari kadar kegiatan belajar peserta didik. Makin tinggi kegiatan belajar peserta didik makin tinggi pula peluang berhasilnya pengajaran. Ini berarti kegiatan mengajar harus merangsang peserta didik melakukan berbagai kegiatan belajar (Sudjana 1989: 72). Sehingga dalam hal ini besar sekali harapan terhadap peran seorang guru dalam meningkatkan mutu pengajarannya menuju peningkatan mutu pendidikan dan kemajuan bangsa. Akan tetapi harapan itu tentu harus didukung dengan fasilitas dan perhatian yang secukupnya terhadap fasilitas dan sarana penunjang yang ikut serta di dalam menentukan keberhasilan proses pendidikan tersebut. Sehingga para pengajar dapat mengkonsentrasikan perhatian untuk mengembangkan ketrampilan dan keilmuannya sesuai dengan profesinya sebagai tenaga pengajar.

Salah satu model pembelajaran yang dapat dilakukan adalah model Jigsaw.
Pembelajaran jigsaw adalah kegiatan pembelajaran yang terfokus pada peserta didik dengan cara membagi peserta didik kedalam beberapa kelompok asal dan membentuk kelompok ahli yang akan membahas sub pokok yang diberikan kepada guru, pada kelompok ahli ini kelompok asal mengirimkan perwakilan kepada kelompok ahli. Setelah selesai, perwakilan kelompok kembali kepada kelompok asal dan perwakilan tersebut mempresentasikan hasil temuannya di kelompok ahli kepada temannya kelompok asal. Pembelajaran jigsaw dapat dilakukan di berbagai tingkatan pendidikan dan tanpa terbatas pada pokok bahasan tertentu, sehingga dalam jenjang pendidikan manapun dapat diterapkan (Suprijono 1990: 46). Dengan menggunakan metode jigsaw diharapkan proses pembelajaran lebih aktif, menyenangkan dan dapat meningkatkan hasil belajar peserta didik khususnya pelajaran matematika.

Dalam prakteknya, pembelajaran kooperatif adalah salah satu bentuk pembelajaran yang berdasarkan faham konstruktivis. Pembelajaran kooperatif merupakan strategi belajar dengan sejumlah peserta didik sebagai anggota kelompok kecil yang tingkat kemampuannya berbeda. Dalam menyelesaikan tugas kelompoknya, setiap peserta didik anggota kelompok harus saling bekerja sama dan saling membantu untuk memahami materi pelajaran. Dalam pembelajaran kooperatif, belajar dikatakan belum selesai jika salah satu teman dalam kelompok belum menguasai bahan pelajaran. Peneliti menjadikan MI Darut Taqwa Banjarmasin sebagai lokasi penelitian dengan dua pertimbangan, yaitu:

1. Menurut hasil observasi dan wawancara di lembaga tersebut dan menemukan masalah dalam pemahaman materi hitung bilangan bulat, dengan demikian sedikit banyak peneliti sudah mengenal lembaga MI Darut Taqwa Banjarmasindan hal ini memudahkan peneliti untuk 
berkomunikasi dengan lembaga terkait.

2. Lembaga tersebut adalah lembaga pendidikan yang sangat besar dan dipercaya oleh masyarakat, hal ini dibuktikan dengan jumlah peserta didik yang sangat banyak, sehingga peneliti sangat tertarik untuk melakukan penelitian di sekolah tersebut.

Berpijak dari berbagai gagasan di atas, maka penulis tertarik untuk mengadakan penelitian dengan judul "Model Jigsaw dalam Pembelajaran Matematika untuk Meningkatkan Hasil Belajar Peserta Didik Kelas V di MI Darut Taqwa Banjarmasin". Adapun fokus penelitiannya adalah:

1. Bagaimana langkah-langkah metode jigsaw dalam pembelajaran operasi hitung bilangan bulat di MI Darut Taqwa?

2. Bagaimana hasil belajar peserta didik melalui metode jigsaw dalam pembelajaran operasi hitung bilangan bulat di MI Darut Taqwa?

\section{METODE PENELITIAN}

Jenis Penelitian yang digunakan dalam penelitian ini adalah Penelitian Tidakan Kelas (PTK) yang dalam Bahasa Inggris PTK disebut Classroom Action Research (CAR). PTK sangat cocok untuk penelitian ini, karena penelitian diadakan dalam kelas dalam penelitian ini lebih difokuskan pada masalah-masalah yang terjadi di dalam kelas atau pada proses belajar mengajar. Peneliti menggunakan model PTK Kemmis \&Mc. Taggart yang dalam alur penelitiannya yakni meliputi langkah - langkah : 1) perencanaan (plan). 2) melaksanakan tindakan (act), 3) melaksanakan pengamatan (observe), dan 4) mengadakan refleksi / analisis (reflection). Sehingga penelitian ini merupakan proses siklus spiral, mulai dari perencanaan, pelaksanaan tindakan, pengamatan untuk modifikas perencanaan, dan refleksi. Penelitian ini juga merupakan penelitian individual.

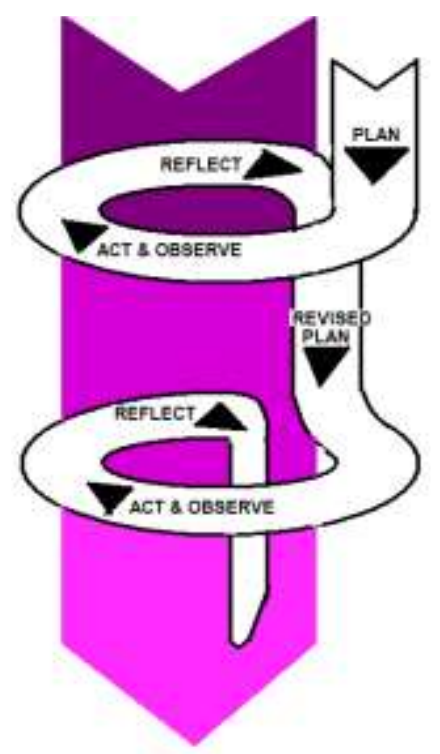

\section{Gambar 1 Siklus PTK model Kemmis dan Taggrat}

Penelitian ini yang menjadi Subjek Penelian adalah peserta didik kelas V MI Darut Taqwa, semester I, berjumlah 20 peserta didik, dengan rincian peserta didik laki-laki 10 anak dan siswi putri 10 anak. Berdasarkan model pengumpulan data, peneliti menganalisa data secara deskriptif, baik deskriptif kualitatif maupun deskriptif kuantitatif. Data yang akan dianalisa secara deskriptif kualitatif berupa data dari hasil pengamatan atau observasi dengan menggunakan intsrumen observasi, sedangkan data yang dianalisis secara deskriptif kuantitatif adalah data tentang hasil tes belajar siswa.

\section{HASIL DAN PEMBAHASAN}

A. Hasil Penelitian

\section{Paparan Data Pra-tindakan (Refleksi Awal)}

Dari hasil test pertama dapat diketahui bahwa peserta didik tuntas adalah $36 \%$ dan peserta didik tidak tuntas adalah $68 \%$. Sedangkan rata-rata skor tes awal peserta didik adalah 57,8. Kegiatan peneliti selanjutnya adalah menentukan kelompok kemampuan peserta didik. Berdasarkan tabel urutan skor tes awal peserta didik, peserta didik dibagi ke dalam tiga bagian, yaitu peserta didik 
berkemampuan tinggi nomor urut 1 s.d. 5 yaitu sebanyak 5peserta didik, peserta didikberkemampuan sedang nomor urut 6 s.d. 15 yaitu sebanyak 10peserta didik, dan peserta didik berkemampuan rendah nomor urut 16 s.d. 20 yaitu sebanyak 5 peserta didik. Pengelompokan peserta didik tersebut selanjutnya digunakan oleh peneliti untuk membentuk kelompok belajar. Peneliti membentuk 4 kelompok asal belajar dan masing-masing kelompok terdiri dari 5 peserta didik yang dipilih secara acak. Dalam satu kelompok selalu ada peserta didik berkemampuan tinggi, peserta didik berkemampuan sedang, dan peserta didik berkemampuan rendah. Secara detil deskripsi masing-masing kelompok dalam dilihat pada tabel berikut:

Tabel 1. Deskripsi Kelompok Asal Belajar

\begin{tabular}{ccc}
\hline Kelompok & \multicolumn{2}{c}{ Kode Peserta didik } \\
\hline \multirow{2}{*}{$\mathbf{1}$} & $\mathbf{2}$ & $\mathbf{3}$ \\
\hline \multirow{2}{*}{ I } & AFS & AH \\
\cline { 2 - 3 } & AF & FIS \\
\cline { 2 - 3 } II & AR & MM \\
\cline { 2 - 3 } & FAK & GRI \\
\cline { 2 - 3 } & ISM & \\
\cline { 2 - 3 } III & MFN & NA \\
\cline { 2 - 3 } & MFS & PA \\
\cline { 2 - 3 } & MKR & R \\
\cline { 2 - 3 } IV & QN & RU \\
\cline { 2 - 3 } & & RI
\end{tabular}

Tabel 2. Deskripsi Kelompok Ahli Belajar

\begin{tabular}{cccc}
\hline Kelompok & \multicolumn{3}{c}{ Kode Peserta didik } \\
\hline $\mathbf{1}$ & $\mathbf{2}$ & $\mathbf{3}$ & $\mathbf{3}$ \\
\hline I & AFS & FAK & RS \\
\cline { 2 - 4 } PENJUMLAHAN & FIS & MFN & \\
\hline II & AF & MFS & R \\
\cline { 2 - 4 } PENGURANGAN & GRI & MKR & \\
\hline III & AR & NA & RU \\
\cline { 2 - 4 } PERKALIAN & ISM & PA & \\
\hline IV & AH & MF & QN \\
\cline { 2 - 4 } PEMBAGIAN & MM & RI & \\
\hline
\end{tabular}

\section{Paparan Data Pelaksanaan Tindakan (Siklus 1)}

Pelaksanaan tindakan siklus I terbagi kedalam empat tahap, yaitu

tahap perencanaan, pelaksanaan, observasi, dan refleksi yang membentuk suatu siklus. Namun dalam paparan data ini peneliti menggambarkan pelaksanaan tindakan siklus 1 sebagai berikut yaitu perencanaan, pelaksanaan, observasi guru, observasi peserta didik, refleksi siklus I dan kendala dan rencana perbaikan siklus 1. Masing-masing tahap dapat dijelaskan sebagai berikut:

\section{a. Tahap perencanaan}

Pada tahap ini kegiatan yang dilakukan pleh peneliti adalah sebagai berikut:

1) Menyiapkan rencana pembelajaran

2) Menyiapkan materi pembelajaran yang akan disajikan (operasi hitung bilangan bulat)

3) Menyiapkan lembar observasi, pedoman wawancara, dan catatan lapangan

4) Menyusun soal kelompok dan soal tes individu (soal tes akhir)

5) Melakukan koordinasi dengan guru Matematika mengenai pelaksanaan tindakan kelas.

\section{b. Tahap pelaksanaan tindakan}

Pelaksanaan tindakan pada siklus pertama ini dilaksanakan pada hari senin dalam satu pertemuan yang terdiri dari dua jam pelajaran. Kegiatan proses belajar yang dilakukan oleh peneliti pada siklus 1 mengacu pada RPP (Rencana Pelaksanaan Pembelajaran) yang disetujui oleh pihak sekolah. Format RPP Siklus 1. 
Tabel 3. Sintak Penerapan Metode Jigsaw

\begin{tabular}{l}
\hline FASE-FASE \\
Fase 1: Presents Goals and set \\
Menyampaikan tujuan dan mempersiapkan \\
peserta didik \\
\\
Fase 2: present information \\
Menyajikan informasi \\
\hline Fase 3: Organize students into learning \\
teams \\
Mengorganisir peserta didik ke dalam tim- \\
tim belajar.
\end{tabular}

PERILAKU GURU

Menjelaskan tujuan pembelajaran dan mempersiapkan peserta

didik siap belajar seperti :

1. Membuka dengan salam

2. Mengabsen peserta didik

3. Memberikan motivasi belajar kepada peserta didik

4. Menyampaikan tujuan pembelajaran

5. Apersepsi : mengingat operasi bilangan bulat

1. Mempresentasikan informasi kepada peserta didik secara verbal materi operasi bilangan bulat

2. Membagikan lembar materi atau modul materi

1. Memberikan penjelasan kepada peserta didik tentang tata cara pembentukan tim belajar dan membantu kelompok melakukan transisi yang efisien

2. Guru menentukan kelompok asal. Membagi peserta didik menjadi 4 kelompok, masing-masing kelompok memiliki 7 anggota.

3. Guru menentukan 7 expert team (tim ahli) 1 kelompok terdiri dari 4 peserta didik yang berasal dari kelompok asal. 7 expert team memiliki pembahasan yang berbeda, 2 kelompok membahas penjumlahan dengan media kartu positif negatif, 2 kelompok membahas pengurangan dengan media kartu positif negatif, 2 kelompok membahas perkalian dengan media garis bilangan, 1 kelompok membahas pembagian dengan media garis bilangan.

Fase 4: Assist team work and study Membantu kerja tim dan belajar

Membantu tim-tim belajar selama peserta didik mengerjakan tugasnya seperti:

1. Guru mengumpulkan peserta didik pada kelompok ahli yang sudah dibentuk dalam pertemuan sebelumnya

2. Membagikan lembar kerja kelompok ahli

3. Guru meminta lembar kerja tersebut untuk didiskusikan dengan kelompoknya masing-masing

4. Guru berkeliling kelas memantau kerja peserta didik

5. Setelah peserta didik menguasai pembahasan tertentu di kelompok ahli, peserta didik kembali ke kelompok asal untuk mendiskusikan hasil pembahasan di kelompok ahli dan mengerjakan soal yang sudah disiapkan untuk tugas kelompok asal

Fase 5: Test on the materials

Mengevaluasi

Fase 6: Provide recognition

Memberikan pengakuan atau penghargaan

\section{c. Tahap Observasi}

Pengamatan dilakukan oleh dua pengamat, yaitu Supriadi selaku guru MatematikaMI Darut Taqwa sebagai pengamat 1 dan WSA sebagai pengamat 2 . Pengamat bertugas mengamati semua aktivitas guru dan aktivitas peserta didik
1. Meminta peserta didik kelompok asal melaporkan hasil kerjanya

2. Guru mengadakan kuis individual dan meminta peserta didik mengerjakan secara individual

Mempersiapkan cara untuk mengakui usaha dan prestasi individu maupun kelompok seperti:

1. Memberi penghargaan kepada kelompok dengan nilai terbaik

2. Membacakan nilai terbaik dalam tes individual

selama pembelajaran berlangsung.

Pengamatan ini dilakukan sesuai pedoman

yang telah disediakan peneliti. Jika ada halhal penting yang terjadi dalam kegiatan pembelajaran dan tidak ada dalam poin pedoman pengamatan, maka hal tersebut dimasukkan sebagai hasil catatan 
lapangan. Berdasarkan hasil pengamatan aktifitas peneliti dan peserta didik pada siklus 1, ada beberapa hal yang tidak sempat dilakukan oleh peneliti. Namun secara umum, kegiatan peneliti sudah sesuai dengan rencana yang ditetapkan. Nilai yang diperoleh dari pengamatan tentang aktivitas guru adalah 77 , nilai yang diperoleh dari pengamatan tentang aktivitas peserta didik adalah 75, sedangkan skor maksimal adalah 90 . Sehingga nilai yang diperoleh rata-rata adalah $\frac{77+75}{2}=76$. Jadi nilai akhir yang didapat adalah: $\frac{75}{90} \times 100 \%=83,3$

Sesuai taraf keberhasilan yang ditetapkan, yaitu:

Taraf Keberhasilan Tindakan:

$90 \% \leq \mathrm{NR} \leq 100 \% \quad$ : Sangat Baik $80 \% \leq \mathrm{NR}<90 \% \quad$ : Baik
$70 \% \leq \mathrm{NR}<80 \% \quad$ : Cukup

$60 \% \leq \mathrm{NR}<70 \% \quad$ : Kurang

$0 \% \leq \mathrm{NR}<60 \% \quad$ : Sangat Kurang

Maka taraf keberhasilan aktivitas peneliti dan peserta didik berada pada kategori Baik.

\section{d. Hasil Tes Akhir}

Skor tes akhir diurutkan berdasarkan urutan jumlah skor tertinggi ke skor terendah pada skala 100 yang dapat dilihat pada lampiran 23. Berdasarkan hasil tes akhir menunjukkan bahwa terjadi peningkatan pemahaman pada peserta didik, peserta didik tuntas adalah $67,8 \%$, sedangkan peserta didik tidak tuntas adalah $33,2 \%$. Hal ini tampak pada rata-rata skor tes akhir lebih baik daripada skor tes awal. Rata-rata skor tes awal adalah 56,8, sedangkan rata-rata skor tes akhir siklus 1 adalah 77,8 .

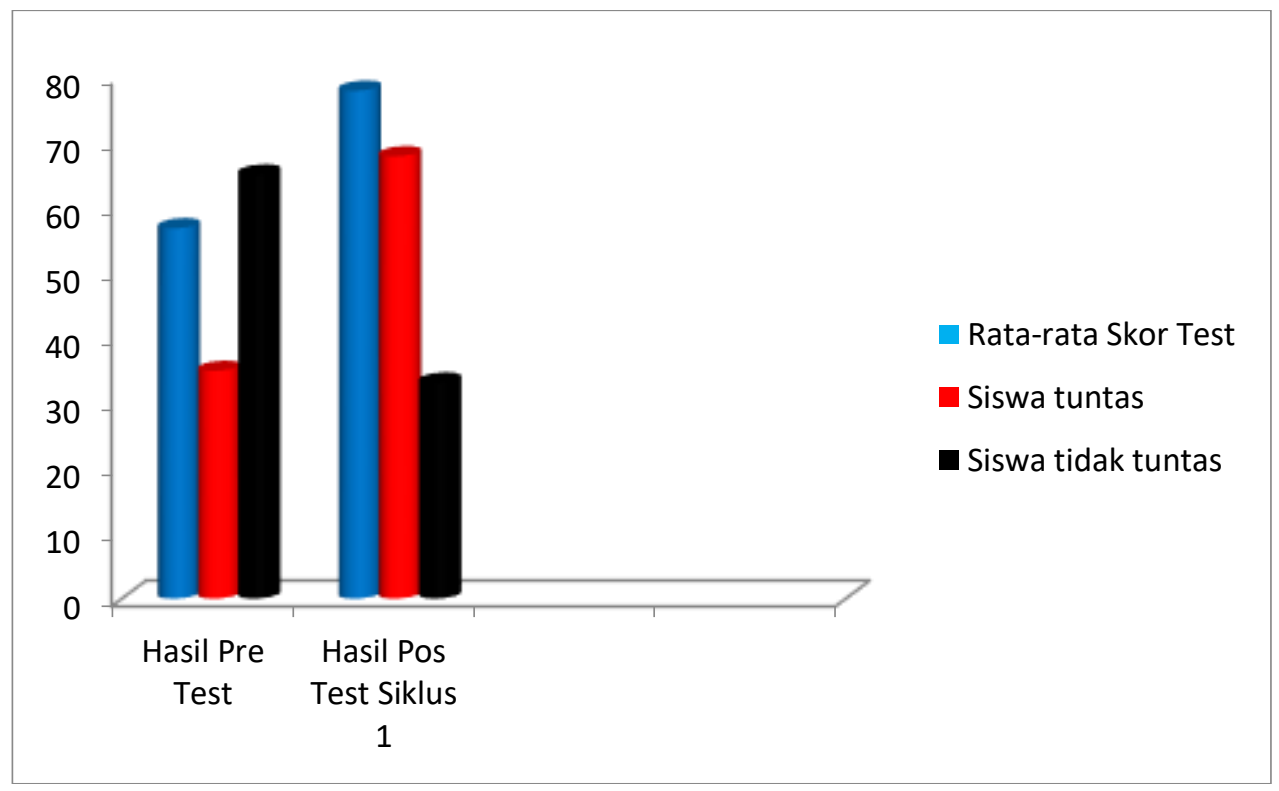

Gambar 2. Peningkatan Hasil Belajar Siklus 1

\section{e. Refleksi}

Berdasarkan kegiatan refleksi terhadap hasil tes akhir, hasil observasi, hasil wawancara, dan hasil catatan lapangan, maka dapat diperoleh beberapa hal yang tercantum pada tabel berikut ini dan susunan rencana perbaikan pada siklus selanjutnya
1) Hasil belajar peserta didik berdasarkan skor tes akhir menunjukkan bahan pemahaman

peserta didik terhadap materi berada pada kriteria baik. Akan tetapi pada proses pembelajaran peserta didik masih tampak lamban dalam menggunakan metode diskusi dengan sesama teman, sehingga diperlukan 
pengulangan siklus agar peserta didik lebih terbiasa menggunakan metode diskusi dalam memecahkan kasus untuk menunjang hasil belajar peserta didik.

2) Aktivitas guru telah menunjukkan tingkat keberhasilan pada kriteria sangat baik. Oleh sebab itu, tidak perlu pengulangan siklus untuk aktivitas guru. Guru hanya perlu mengkondisikansa agar lebih konsentrasi pada pembelajaran.

3) Aktivitas peserta didik menunjukkan tingkat keberhasilan pada kriteria sangat baik. Akan tetapi masih perlu melakukan pengulangan siklus karena ada beberapa peserta didik yang kurang aktif pada proses belajar kelompok. Selain itu masih ada peserta didik yang ramai memperbincangkan hal-hal diluar materi pembelajaran sehingga mengganggu konsentrasi peserta didik lain.

4) Kegiatan pembelajaran menunjukkan penggunaan waktu yang sudah sesuai rencana. Oleh sebab itu, tidak diperlukan siklus untuk mengatur penggunaan waktu.

5) Kegiatan pembelajaran menunjukkan ada beberapa peserta didik yang belum aktif dalam kegiatan pembelajaran. Sehingga diperlukan pengulangan siklus untuk meningkatkan keaktifan peserta didik dalam kegiatan pembelajaran.

6) Pemahaman peserta didik terhadap materi operasi hitung bilangan bulat di kategori di bawah KKM ( Kriteria Ketuntasan Minimal) yaitu 70 sehingga diperlukan pengulangan siklus.

Berdasarkan hasil refleksi dapat disimpulkan bahwa masih diperlukan pengulangan siklus untuk meningkatkan keaktifan peserta didik dalam kegiatan pembelajaran dan melatih peserta didik agar terbiasa menggunakan metode diskusi dalam memecahkan masalah guna menunjang hasil belajarnya.

\section{f. Kendala dan Rencana Perbaikan pada Siklus 2}

Pada pelaksanaan siklus 1 peneliti menemukan beberapa kendala dalam pelaksanaan pembelajaran matematika pada meteri operasi bilangan bulat. Dengan adanya kendala pada siklus 1 peneliti membuat rencana perbaikan pada siklus 2 agar proses pembelajaran dengan model Jigsaw berjalan dengan baik. Adapun kendala dan rencana perbaikan dapat dilihat pada tabel.

Tabel 4. Kendala dan Rencana Perbaikan pada Siklus 2

\begin{tabular}{|c|c|c|}
\hline No & Kendala Siklus 1 & $\begin{array}{r}\text { Rencana Perbaikan Siklus } 2 \\
\end{array}$ \\
\hline 1 & $\begin{array}{l}\text { Suasana kelas agak ramai saat peserta didik melakukan } \\
\text { kerja kelompok, bahkan ada peserta didik yang asyik } \\
\text { membicarakan hal-hal diluar materi pembelajaran }\end{array}$ & $\begin{array}{l}\text { Guru atau peneliti berpesan kepada seluruh peserta didik } \\
\text { apabila berdiskusi tidak boleh ramai dan tidak boleh } \\
\text { membicarakan hal-hal diluar materi pembelajaran }\end{array}$ \\
\hline 2 & $\begin{array}{l}\begin{array}{l}\text { Peserta didik masih ragu-ragu untuk mengajukan } \\
\text { pertanyaan }\end{array} \\
\end{array}$ & $\begin{array}{l}\text { Guru memberikan kesempatan peserta didik untuk } \\
\text { bertanya dengan pendekatan personal apabila ada yang } \\
\text { belum paham }\end{array}$ \\
\hline 3 & $\begin{array}{l}\text { serta didik masih segan dan takut untuk mengajukan } \\
\text { ndapat }\end{array}$ & $\begin{array}{l}\text { Guru berpesan agar peserta didik tidak takut dalam } \\
\text { mengajukan pendapat baik secara klasikal, kelompok } \\
\text { maupun personal }\end{array}$ \\
\hline 4 & $\begin{array}{l}\text { eserta didik MS saat pembelajaran tidak mau berdiskusi } \\
\text { an lebih memilih duduk di bawah meja }\end{array}$ & $\begin{array}{l}\text { Guru melakukan pendekatan personal dengan member } \\
\text { motivasi kepada peserta didik MS agar mau mengikuti } \\
\text { pembelajaran dengan menggunakan metode jigsaw dan } \\
\text { duduk di kursi kelompoknya }\end{array}$ \\
\hline 5 & $\begin{array}{l}\text { eserta didik RAS saat pembelajaran suka menggoda } \\
\text { mannya saat berdiskusi baik teman kelompok maupun } \\
\text { luar kelompoknya }\end{array}$ & $\begin{array}{l}\text { Guru melakukan pendekatan personal dengan } \\
\text { memberikan motivasi agar tidak lagi menggoda } \\
\text { temannya saat berdiskusi }\end{array}$ \\
\hline 6. & $\begin{array}{l}\text { Pemahaman peserta didik masih pada kriteria cukup dan di } \\
\text { bawah KKM (Kriteria Kentuntasan Minimal) yang telah } \\
\text { ditentukan oleh pihak sekolah. }\end{array}$ & $\begin{array}{l}\text { Guru memberikan motivasi kepada peserta didik untuk } \\
\text { belajar dengan giat agar hasil belajar peserta didik dapat } \\
\text { meningkat. }\end{array}$ \\
\hline
\end{tabular}




\section{Paparan Data Pelaksanaan Tindakan (Siklus 2)}

Pelaksanaan tindakan terbagi ke dalam empat tahap, yaitu tahap perencanaan, pelaksanaan, observasi dan refleksi yang membentuk suatu siklus. Secara lebih rinci, masing-masing tahap dapat dijelaskan sebagai berikut.

a. Tahap perencanaan

Pada tahap ini kegiatan yang dilakukan oleh peneliti adalah sebagai berikut:

1) Menyiapkan rencana pembelajaran

2) Menyiapkan materi pembelajaran yang akan disajikan (operasi hitung bilangan bulat)

3) Menyiapkan lembar observasi, pedoman wawancara, dan catatan lapangan

4) Menyusun soal kelompok II dan soal tes individu (soal tes akhir)

5) Melakukan koordinasi dengan guru Matematika mengenai pelaksanaan tindakan.

\section{b. Tahap observasi}

Pengamatan dilakukan oleh dua orang pengamat yang sama pada siklus kedua yaitu wali kelas selaku guru Matematika Kelas V di MI Darut Taqwa sebagai pengamat 1 dan WSA selaku peneliti 2 dan memasuki ruangan kelas 5 bersamaan dengan peneliti. Pengamatan dilakukan dengan menggunakan pedoman pengamatan yang telah disediakan oleh peneliti. Jika ada hal-hal penting yang terjadi dalam kegiatan pembelajaran dan tidak ada dalam poin pedoman pengamatan, maka hal tersebut dimasukkan sebagai hasil catatan lapangan.. Nilai yang diperoleh dari pengamat 1 adalah 63 dan nilai yang diperoleh pengamat 2 adalah 66, sedangkan skor maksimal adalah 70 . sehingga nilai yang diperoleh rata-rata adalah $\frac{63+64}{2}=63,5$.

$$
\text { Nilai }=\frac{63,5}{70} \times 100 \%=90,7 \%
$$

Sesuai taraf keberhasilan yang telah ditetapkan, maka taraf keberhasilan aktivitas peneliti dan peserta didik berada pada kategori sangat baik. Adapun peningkatan keberhasilan aktivitas peneliti dari siklus 1 sampai siklus 2 dapat dilihat pada gambar 3 berikut:

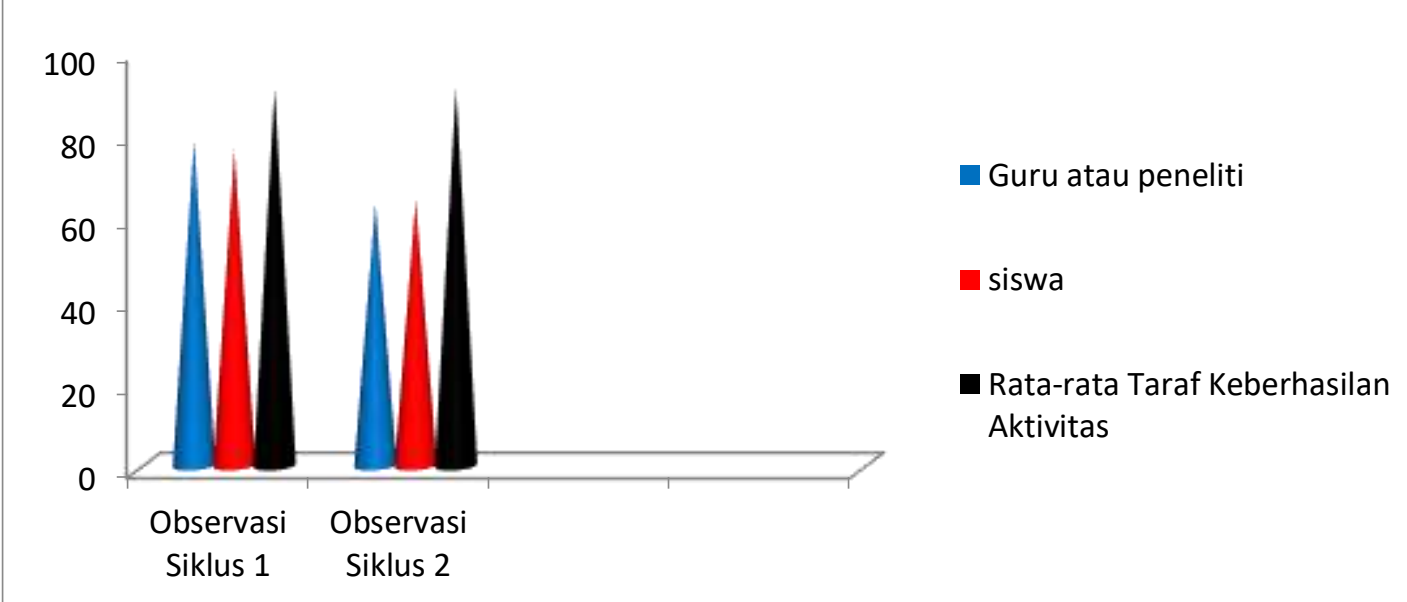

Gambar 3 Peningkatan Keberhasilan Aktivitas Peneliti

\section{c. Hasil Tes Akhir}

Berdasarkan hasil tes akhir pada sikuls kedua menunjukkan bahwa terjadi meningkatan pemahaman pada peserta didik. Hal ini tempat pada peningkatan rata-rata skor kedua adalah 81,2 sedangkan rata-rata skor tes akhir siklus pertama 
Jurnal PTK \& Pendidikan

Vol. 3 No. 1. Januari - Juni 2017 (23-34)

adalah 77,8. adapun peserta didik yang tuntas pada siklus 2 adalah 78,5\%, sedangkan peserta didik tuntas pada siklus 1 adalah $67,8 \%$, dan peserta didik yang tidak tuntas pada siklus 2 adalah 21,5\%, sedangkan peserta didik tidak tuntas pada siklus 1 adalah 33,2. Adapun gambar peningkatan hasil belajar dari test awal, post test siklus 1 dan post test siklus 2 dapat dilihat pada gambar 3:

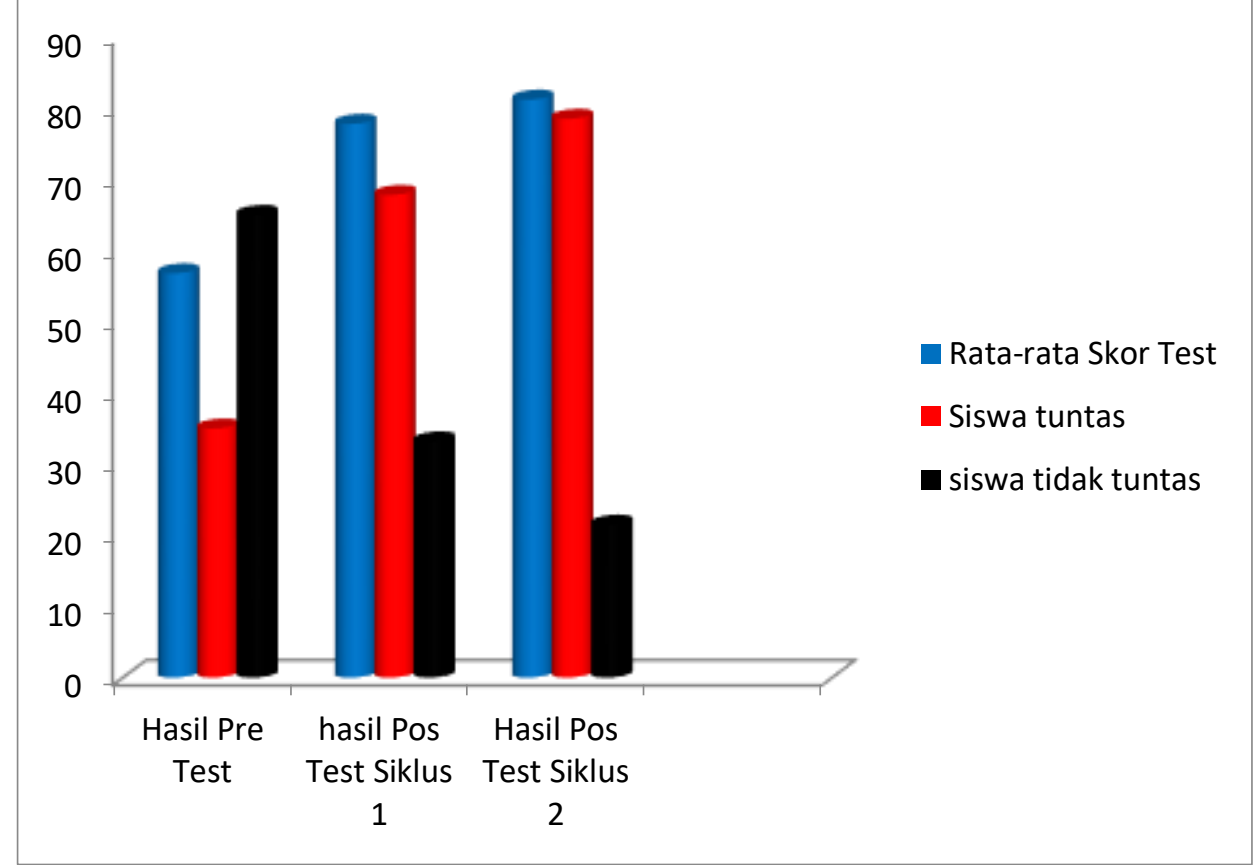

Gambar 4 Peningkatan Hasil Belajar 


\section{Refleksi}

Berdasarkan kegiatan refleksi terhadap hasil tes akhir, hasil pengamatan, hasil wawancara, dan hasil catatan lapangan pada siklus kedua, maka dapat diperoleh beberapa hal berikut.

1) Hasil belajar peserta didik berdasarkan skor tes akhir menunjukkan peningkatan yang cukup baik dari tes sebelumnya. Hal ini menunjukkan bahwa pemahaman peserta didik terhadap materi pembelajaran semakin meningkat. Oleh karena itu, tidak perlu pengulangan siklus untuk meningkatkan hasil belajar peserta didik. Aktivitas guru telah menunjukkan tingkat keberhasilan pada kriteria sangat baik. Oleh karena itu, tidak perlu pengulangan siklus untuk aktivitas guru.

2) Aktivitas peserta didik telah menunjukkan tingkat keberhasilan pada kriteria sangat baik. Oleh karena

itu tidak perlu pengulangan siklus untuk aktivitas peserta didik.

3) kegiatan pembelajaran menunjukkan penggunaak waktu yang sudah sesuai rencana. Oleh sebab itu, tidak diperlukan pengulangan siklus untuk mengatur waktu.

4) Kegiatan pembelajaran telah menunjukkan keaktifan peserta didik dalam kegiatan pembelajaran. Sehingga tidak diperlukan pengulangan siklus untuk meningkatkan keaktifan peserta didik dalam kegiatan pembelajaran.

Berdasarkan hasil refleksi dapat disimpulkan bahwa setelah pelaksanaan tindakan pada siklus kedua ini tidak diperlukan pengulangan siklus karena secara umum kegiatan pembelajaran telah berjalan sesuai rencana. Peserta didik telah dapat berdiskusi dalam memecahkan masalah sebagai sarana untuk meningkatkan pemahamannya terhadap materi pembelajaran serta meningkatkan keaktifan peserta didik dalam proses pembelajaran.

\section{PENUTUP}

Berdasarkan paparan data, temuan penelitian, dan pembahasan pada Bab IV maka kesimpulan penelitian ini adalah sebagai berikut:

1. Langkah-langkah pembelajaran melalui metode jigsaw pada pelajaran matematika pada pokok bahasan operasi bilangan bulat adalah a) Menyampaikan tujuan dan mempersiapkan peserta didik. b) Menyajikan informasi. c) Mengorganisir peserta didik ke dalam tim-tim belajar. d) Membantu kerja tim dan belajar. e) Mengevakuasi. f) Memberikan pengakuan atau penghargaan

2. Model diskusi teknik Jigsaw sangat efektif untuk meningkatkan keberhasilan belajar peserta didik. Hal ini dibuktikan dengan tingkat keberhasilan belajar peserta didik yang cukup memuaskan yang dapat diketahui dari indikator keberhasilan yang berupa nilai hasil belajar peserta didik dan proses pembelajaran. Proses belajar sangat menentukan hasil belajar. Nilai rata-rata hasil belajar peserta didik pada pre-test adalah 57,8, pada tes akhir siklus pertama adalah 77,8 , sedangkan pada tes akhir siklus kedua adalah 83,3. Nilai hasil belajar ini tingkat keberhasilanya berada pada criteria sangat baik. Sedangkan ketuntasan peserta didik pada pre-test adalah $36 \%$, pada siklus 1 peserta didik tuntas adalah 67,8 dan siklus 2 adalah $78,5 \%$

\section{DAFTAR PUSTAKA}

Anonim.

http://sunartombs.wordpress.com/2 009/06/15/pengertian-danpenerapan-metode-jigsaw/ 
Hudojo, Herman. 2005.Pengembangan Kurikulumdan Pembelajaran Matematika, Malang:UNM, 2005

Jihat,Asep. 2008. Pengembangan Kurikulum matematika. Yogyakarta : Multi pressindo

Lie, Anita, 2007. Cooperative Learning, Jakarta: Grasindo.

Masykur, M. \& Fathani, Abdul Halim. 2008.Mathematical Intelligence. Jogjakarta: Ar-Ruzz Media

Purwanto. 2009. Evaluasi Hasil Belajar. Yogyakarta : Pustaka Pelajar

Soedjadi. 1999. Kiat pendidikan Matematika di Indonesia. Jakarta: Dirjen Perguruan Tinggi Depdiknas.

Sudjana, Nana.1987. Dasar-Dasar Proses Belajar Mengajar.Bandung: Sinar Baru Algensindo

Suprijono, Agus. 2010.Coperative Learning Teori dan Aplikasi PAIKEM. Yogyakarta: Pustaka Pelajar

Suryobroto,B. 1997.Proses Belajar Mengajar di Sekolah. Jakarta: Rineka Cipta

Suwarna.2006.Pengajaran Mikro. Jakarta : Tiara Wacana

Trigan, Djago.1990. Proses Belajar

Mengajar Pragmatik, Bandung: Angkasa 